\title{
Characteristics and Functional Capacities of Human Cord Blood Granulocytes and Monocytes
}

\author{
L. MARÓDI ${ }^{1}$, P. C. J. LEIJH, AND R. VAN FURTH \\ Department of Infectious Diseases Leiden University Hospital, Leiden, The Netherlands [P.C.J.L., R.v.F.] and \\ Department of Pediatrics, University Medical School of Debrecen [L.M.], Debrecen, Hungary
}

\begin{abstract}
Cord blood phagocytic cells were characterized with respect to cytochemical activities, $\mathrm{Fc} \gamma$ and $\mathbf{C 3 b}$ receptors, and capacity to phagocytose and kill various species of bacteria.

The percentages of peroxidase-positive granulocytes and monocytes from neonates and adults were comparable; the percentage of esterase-positive cord-blood monocytes was about two-thirds of that of adults' blood monocytes. The numbers of cord blood and adults' monocytes with $\mathrm{Fc} \gamma$ and C3b receptors were similar.

Phagocytic and intracellular killing capacities of cord blood granulocytes and monocytes were investigated for Staphylococcus aureus, Escherichia coli, Streptococcus pyogenes, and group B Streptococcus type III. The rates of phagocytosis and intracellular killing by granulocytes from newborns proved to be comparable to the corresponding values for granulocytes from adults.

Cord blood monocytes phagocytosed $E$. coli, $S$. aureus, and $S$. pyogenes at a normal rate, and killed ingested $E$. coli and $S$. pyogenes intracellularly at the same rate as adults' monocytes did. However, $S$. aureus was killed at a much lower rate by cord blood monocytes than by monocytes from adults. Phagocytic activity for group B Streptococcus was impaired and killing of these bacteria by cord blood monocytes was virtually nil. The latter finding might partially explain the frequent streptococcal infections in newborns. (Pediatr Res 18:1127-1131, 1984)
\end{abstract}

\section{Abbreviation}

HBSS, Hanks' balanced salt solution

Despite improved diagnostic techniques and medical care, bacterial infections still play an important role in neonatal morbidity and mortality. A wide variety of microorganisms, including those considered to have relatively low virulence and to be susceptible to commonly used antibiotics, can lead to overwhelming septicemia in neonates. The frequency of infections in the newborn suggests a defective host defense mechanism, and various attempts have been made to investigate this point. Particular attention has been paid to the functioning of phagocytic cells. Defects in the chemotactic motility of granulocytes and monocytes (reviewed in Ref. 18) and impaired opsonization of

Received August 1, 1983; accepted March 12, 1984

Correspondence may be addressed to R. van Furth, Department of Infectious Diseases, Leiden University Hospital, Rijnsburgerweg 10, 2333 AA Leiden, The Netherlands.

Present address: Department of Pediatrics, University Medical School of Debrecen, 4012 Debrecen. Pf::32. Hungary. Dr. Maródi was the recipient of a grant from the Netherlands Ministry of Education.
Gram-negative microorganisms by sera of newborns have been reported (7). The phagocytic function of newborn's granulocytes is normal, and bactericidal killing by these cells has been reported to be normal or decreased $(4,5,8,20,22,25)$. Studies on monocytes from newborns have been hampered because the available techniques required too much blood. Recently, we developed a micromethod (19) which permits detailed investigation of the functional activities of newborns' granulocytes and monocytes.

The present paper describes the cytochemical characteristics, the metabolic activity, and the phagocytic and microbicidal activities of human cord blood granulocytes and monocytes as well as the occurrence of $\mathrm{Fc} \gamma$ and $\mathrm{C} 3 \mathrm{~b}$ receptors on these cells.

\section{MATERIALS AND METHODS}

Blood samples. Five to $10 \mathrm{ml}$ blood (anticoagulated with 20 units/ml heparin) was collected aseptically from the placental end of the cut umbilical cord of 45 healthy full term infants ( 21 males and 24 females) at normal delivery in the Department of Obstetrics and Gynaecology of the Leiden University Hospital. For control studies, 10 to $15 \mathrm{ml}$ blood was obtained by venipuncture from 60 healthy adult donors.

Isolation of monocytes and granulocytes. Monocytes were collected by differential centrifugation of $5 \mathrm{ml}$ heparinized blood on Ficoll-Hypaque gradients; granulocytes were obtained from the Ficoll-Hypaque pellet by dextran sedimentation (19). Monocytes and granulocytes were suspended in HBSS with $0.1 \%$ gelatin to a concentration of $10^{7}$ cells $/ \mathrm{ml}$. Cell counts were done in a Bürker hemocytometer; differential counts were made in Giemsa-stained cytocentrifuge preparations (9).

Cytochemical stainings. The percentage of peroxidase-positive cells was determined in cytocentrifuge preparations according to Kaplow (12) with benzidine dihydrochloride (Fluka, Buchs, Switzerland) as substrate (pH 6.0) and hydrogen peroxide at a concentration of $0.002 \%(\mathrm{vol} / \mathrm{vol})$.

Esterase activity was investigated in cytocentrifuge preparations according to Ornstein (10) with $\alpha$-naphthyl butyrate (Sigma Chemical Co., St. Louis, MO) as substrate (pH 6.1) and incubation at room temperature for $25 \mathrm{~min}$.

Serum. Serum was obtained from healthy AB blood group donors and stored in small aliquots at $-70^{\circ} \mathrm{C}$.

Microorganisms. Staphylococcus aureus (type 42D), Escherichia coli (054), Streptococcus pyogenes, and a clinical isolate of group B Streptococcus type III (Streptococcus agalactiae) (kindly provided by Dr. D. G. Groothuis, Rijksinstitutt voor de Volksgezondheid, Bilthoven) were cultured overnight at $37^{\circ} \mathrm{C}$ in Nutrient Broth No. 2 (Oxoid Ltd., London), harvested by centrifugation at $1500 \times g$ for $10 \mathrm{~min}$, washed twice with phosphatebuffered saline and finally suspended in gelatin-HBSS to a concentration of $10^{7}$ bacteria $/ \mathrm{ml}$. All bacteria were serum resistant, 
i.e. incubation of $5 \times 10^{6} \mathrm{bacteria} / \mathrm{ml}$ in $90 \%$ serum for $2 \mathrm{~h}$ at $37^{\circ} \mathrm{C}$ did not decrease the number of viable bacteria.

Pre-opsonization of bacteria was performed by incubating $5 \times$ $10^{6}$ bacteria $/ \mathrm{ml}$ with $10 \%(\mathrm{vol} / \mathrm{vol}) \mathrm{AB}$ serum for $30 \mathrm{~min}$ at $37^{\circ}$ $\mathrm{C}$ at 4 rotations/min, next, the suspension was cooled to $4^{\circ} \mathrm{C}$ and the excess serum removed by centrifugation and two washes with ice-cold HBSS. The bacteria were then resuspended in gelatin-HBSS to a concentration of $10^{7} / \mathrm{ml}$.

Micromethod to determine phagocytosis. Phagocytosis by monocytes and granulocytes was measured as the decrease in the number of viable extracellular bacteria during incubation of bacteria and phagocytes in the presence of serum. In short, $10^{6}$ phagocytic cells were incubated with $10^{6}$ bacteria in a total volume of $200 \mu \mathrm{l}$ in the presence of $20 \mu \mathrm{l}$ serum, at $37^{\circ} \mathrm{C}$ at 4 rotations/min. After various intervals, $50-\mu$ l aliquots were taken and added to $450 \mu \mathrm{l}$ ice-cold HBSS, after which the cells were centrifuged for $6 \mathrm{~min}$ at $75 \times g$ and the number of viable extracellular bacteria was determined by plating serial 10 -fold dilutions on DST agar plates (Diagnostic Sensitivity Medium Agar, Oxoid Ltd., London). The plates were incubated at $37^{\circ} \mathrm{C}$ for $24 \mathrm{~h}$, after which the number of viable bacteria/ml was calculated from the colony counts (19).

Phagocytosis at a given time point was expressed as the percentage decrease of the initial number of the viable extracellular bacteria.

Micromethod to assess intracellular killing. Intracellular killing of microorganisms was measured as the decrease in the number of viable intracellular bacteria during incubation of phagocytes containing ingested bacteria (19). In brief, $10^{6}$ pre-opsonized bacteria were incubated with $10^{6}$ monocytes or granulocytes in a suspension of $200 \mu \mathrm{l}$ for $3 \mathrm{~min}$ at $37^{\circ} \mathrm{C}$ under at 4 rotations/ min. Phagocytosis was stopped by rapid chilling to $4^{\circ} \mathrm{C}$ in ice, and the noningested bacteria were removed by differential centrifugation and two washes with ice-cold HBSS. Next, the phagocytic cells containing ingested bacteria were resuspended to a concentration of $5 \times 10^{6} \mathrm{l} / \mathrm{ml}$ (volume of $200 \mu \mathrm{l}$ ) and incubated at $37^{\circ} \mathrm{C}$ under 4 rotations $/ \mathrm{min}$ in the presence of $10 \% \mathrm{AB}$ serum. At various time points, a $50-\mu \mathrm{l}$ sample was taken added to 450 $\mu \mathrm{l}$ distilled water to disrupt granulocytes. Lysis of monocytes was achieved by three cycles of freezing and thawing in liquid nitrogen. Next, serial 10 -fold dilutions of the lysate were made and the number of viable bacteria was determined by colony counts as described under the phagocytosis assay.

Intracellular killing at a given time point was expressed as the percentage decrease in the initial number of the viable intracellular bacteria.

$F c \gamma$ and $C 3 b$ receptors. The presence of $F c \gamma$ and $\mathrm{C} 3 \mathrm{~b}$ receptors on cord blood monocytes was investigated in cytocentrifuge preparations with IgG-coated sheep erythrocytes and IgM- and complement-coated sheep erythrocytes, as described elsewhere (10).

Oxygen $\left(\mathrm{O}_{2}\right)$ consumption by cord blood phagocytes. The consumption of $\mathrm{O}_{2}$ by cord blood granulocytes and monocytes was assessed as the decrease in the $\mathrm{O}_{2}$ concentration of the extracellular medium in suspension, measured with a Clark-type oxygen electrode (30) (Oxygen Monitor, Yellow Springs Instruments, Yellow Springs, $\mathrm{OH})$.

Hydrogen peroxide $\left(\mathrm{H}_{2} \mathrm{O}_{2}\right)$ production by cord blood phagocytes. $\mathrm{H}_{2} \mathrm{O}_{2}$ production was measured as the oxidation of fluorescent scopoletin to its nonfluorescent product as described by Root et al. (28). $2.5 \times 10^{6}$ phagocytic cells in $3 \mathrm{ml}$ HBSS without phenyl red were incubated in the presence of $10 \mathrm{nM}$ scopoletin (Sigma Chemical Co.), $1 \mathrm{mM} \mathrm{NaN}_{3}$, and 30 units horseradish peroxidase (Sigma) at $37^{\circ} \mathrm{C}$; fluorescence was recorded with a Perkin-Elmer 3000 spectrophotometer (Perkin-Elmer, Beaconsfield, England) at $460 \mathrm{~nm}$ when activated at $360 \mathrm{~nm} . \mathrm{H}_{2} \mathrm{O}_{2}$ production was induced by the addition of $10^{9}$ opsonized heatkilled $S$. aureus.

Calculations. All results are means and standard deviations of at least five experiments performed with five different cord blood samples on different days. Data on cells from healthy adults, i.e. control cells, are means and standard deviations of at least 10 experiments performed on different days. The results of the various kinds of experiment, i.e. the percentage cells with receptors, the percentage phagocytosis, and the percentage of intracellular killing obtained for cells of healthy adults, followed a log normal distribution. Statistical analysis to compare data of cord cells with cells of healthy adults was performed with a two-tailed Student's $t$ test for unpaired observations after logarithmic transformation of the results.

The results of the experiments on $\mathrm{O}_{2}$ consumption and $\mathrm{H}_{2} \mathrm{O}_{2}$ production experiments by cord blood cells were compared with the results of similar experiments with adult cells on the same day. Statistical analysis of these results was performed on a $t$ test for comparison of means for paired samples.

\section{RESULTS}

Number of phagocytic cells in cord blood. The absolute numbers of granulocytes and monocytes in heparinized cord-blood were calculated on the basis of the total number of white cells and the differential count and amounted to $5.6 \times 10^{9} /$ liter (range, $2-8 \times 10^{9}$ ) and $0.8 \times 10^{9} /$ liter (range, $0.2-1.3 \times 10^{9}$ ), respectively. After differential centrifugation of cord blood on Ficoll-Hypaque, approximately $60 \pm 15 \%$ of the granulocytes and $90 \pm 13 \%$ of the cord monocytes were recovered.

Cytochemical characteristics of cord blood phagocytes. Esterase staining revealed that only $58 \%$ of the cord blood monocytes were esterase positive, which is significantly lower $(p<0.001)$ than the corresponding percentage of adults' monocytes (Table 1).

Peroxidase staining revealed similar percentages of monocytes containing peroxidase-positive granules for newborn and adults ( $p>0.1$; Table 1). Almost all of the cord blood granulocytes were peroxidase positive (data not shown).

$F c \gamma$ and $C 3 b$ receptors on cord blood monocytes. The percentage of blood monocytes with $\mathrm{Fc} \gamma$ and $\mathrm{C} 3 \mathrm{~b}$ receptors did not differ between adults and newborns ( $p>0.1$; Table 1$)$.

Phagocytosis of microorganisms by cord blood granulocytes. Phagocytosis of $E$. coli, $S$. aureus, $S$. pyogenes, and group B streptococci by cord blood and adults' granulocytes at a bacteriato-cell ratio of $1: 1$ at $37^{\circ} \mathrm{C}$ was equally effective $(p>0.1$; Fig. 1). A 10 -fold increase in the number of bacteria relative to the number of granulocytes did not alter either the rate or degree of phagocytosis over a period of 120 min (data not shown). In control experiments in which the various bacteria and granulocytes were incubated in the absence of serum or in the presence of serum but without rotation, no phagocytosis occurred.

Intracellular killing activity of cord blood granulocytes. After incubation of cord granulocytes containing $E$. coli, $S$. aureus, $S$. pyogenes, or group B streptococci, for $120 \mathrm{~min}$, the number of viable intracellular bacteria was decreased to a comparable degree as found for adults' granulocytes (for all bacteria species, $p>0.1$; Fig. 2).

Phagocytosis of microorganisms by cord blood monocytes. Incubation of cord and adults' monocytes with $E$. coli, S. aureus,

Table 1. Cytochemical characteristics and surface receptors of blood monocytes from neonates and adults*

\begin{tabular}{lllc}
\hline & $\begin{array}{c}\text { Cord blood } \\
\text { monocytes } \\
(\%)\end{array}$ & $\begin{array}{c}\text { Adult blood } \\
\text { monocytes } \\
(\%)\end{array}$ & $p$ \\
\hline Esterase activity & $58.0 \pm 13.0$ & $95.0 \pm 3.0$ & $<0.001$ \\
Peroxidase activity & $90.4 \pm 1.7$ & $87.2 \pm 6.4$ & $\mathrm{NS}$ \\
IgG receptors & $89.8 \pm 13.6$ & $96.7 \pm 2.6$ & $\mathrm{NS}$ \\
C3b receptors & $84.0 \pm 9.0$ & $82.7 \pm 5.5$ & $\mathrm{NS}$ \\
\hline
\end{tabular}

* Values are mean (percentage) and standard deviations of 10 samples. NS, not statistically significant $(p>0.1)$. 


\section{Escherichia coli}

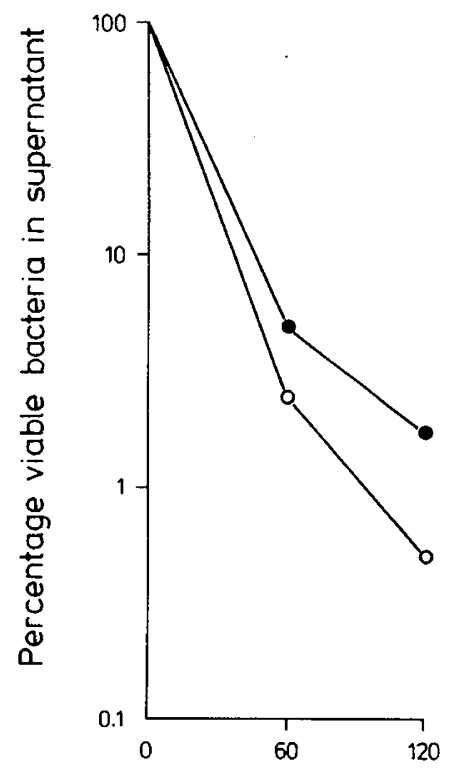

Staphylococcus aureus Streptococcus pyogenes

Group B streptococcus

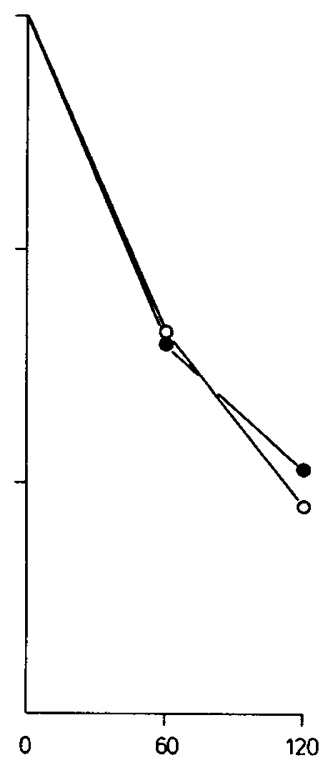

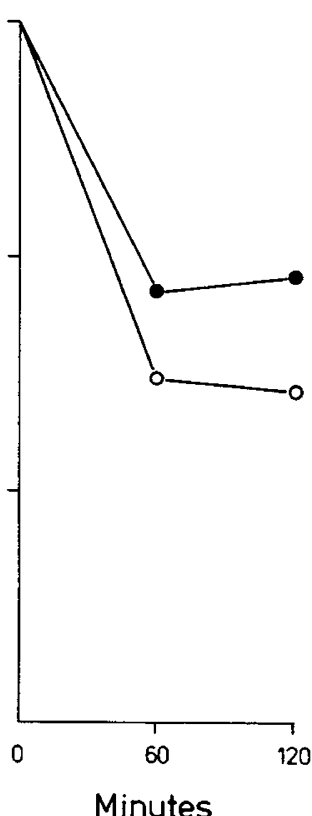

Fig. 1. Phagocytosis of microorganisms by cord blood $(\bullet)$ and adults' $(O)$ granulocytes. The results are the means of at least five experiments with maximal standard deviations of $5 \%$.

Escherichia coli

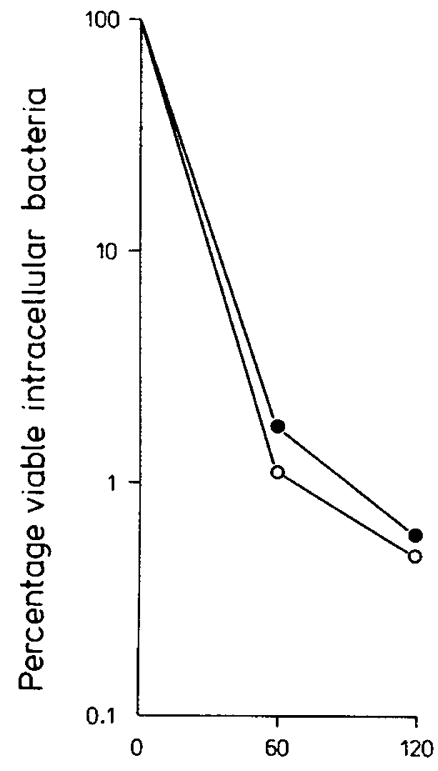

Staphylococcus aureus

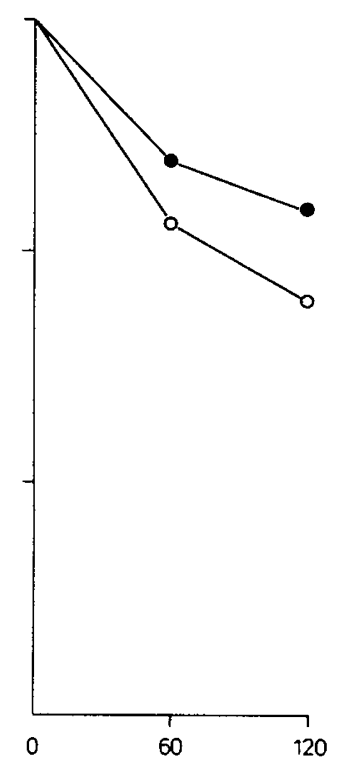

Streptococcus pyogenes

Group B streptococcus
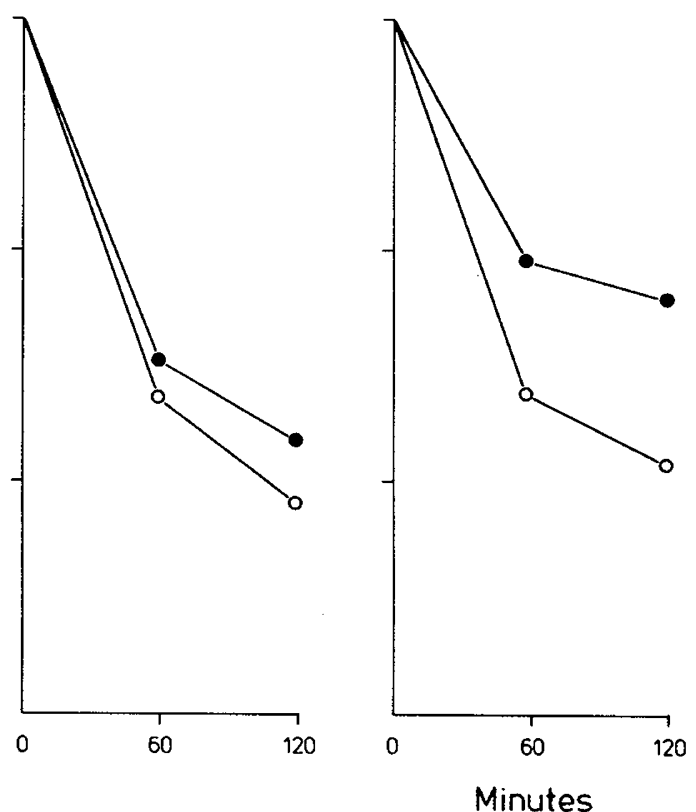

Fig. 2. Intracellular killing of microorganisms by cord blood $(\bullet)$ and adults' $(O)$ granulocytes. The results are the means of at least five experiments with a standard deviation of maximally $9 \%$.

or $S$. pyogenes gave a comparable decrease in the number of viable extracellular bacteria (for all three species: $p>0.1$; Fig. 3 ). When the bacteria-to-monocyte ratio was $10: 1$ instead of $1: 1$, there was no change in the rate of ingestion of bacteria by cord monocytes (data not shown).

Incubation of cord and adults' monocytes with group B streptococci at a ratio of $1: 1$ showed a lower rate of phagocytosis in the former $(p<0.01)$ (Fig. 3). At a bacteria-to-monocyte ratio of 10:1, the ingestion of group B streptococci was also decreased (data not shown).

Intracellular killing activity of cord blood monocytes. Incuba- tion of cord and adults' monocytes containing ingested $E$. coli or $S$. pyogenes revealed no divergence in the rate of intracellular killing of these microorganisms $(p>0.1$; Fig. 4). However, no intracellular killing of $S$. aureus by newborns' monocytes was observed, whereas the intracellular killing of group B streptococci by cord blood monocytes $(58 \pm 10 \%, n=5$ at $120 \mathrm{~min}$ ) was suboptimal compared with the killing by adults' blood monocytes $(97 \pm 2, n=10$ at $120 \mathrm{~min}$ ) (Fig. 4).

$\mathrm{O}_{2}$ consumption and $\mathrm{H}_{2} \mathrm{O}_{2}$ production by cord blood phagocytes. Determination of the metabolic burst activity of cord blood granulocytes and monocytes, as reflected by $\mathrm{O}_{2}$ consumption 


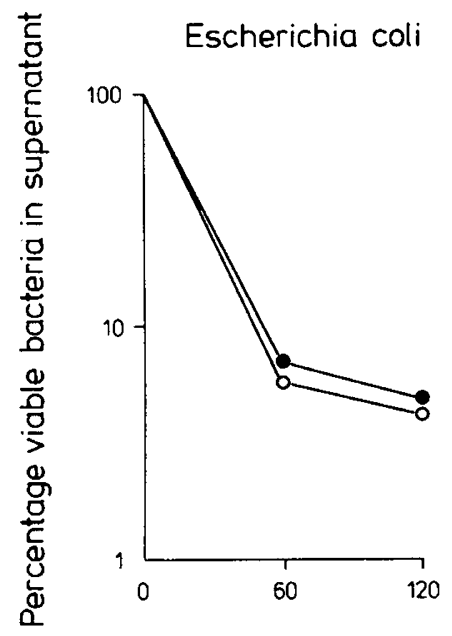

\section{Staphylococcus aureus Streptococcus pyogenes Group B streptococcus}
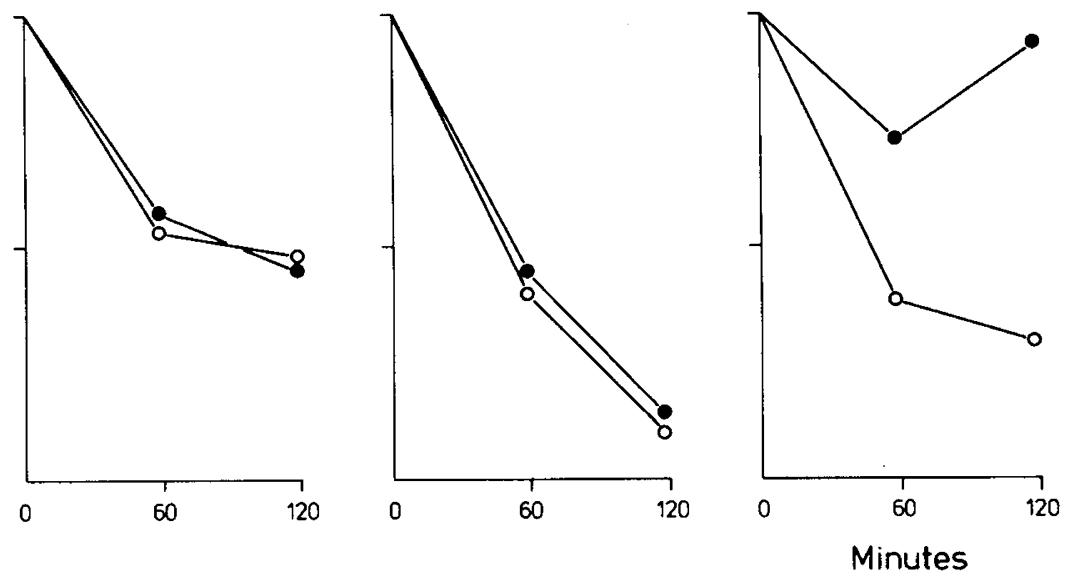

Fig. 3. Phagocytosis of microorganisms by cord blood $(\bullet)$ and adults' $(O)$ monocytes. The results are the means of at least five experiments with a maximal standard deviation of $7 \%$.
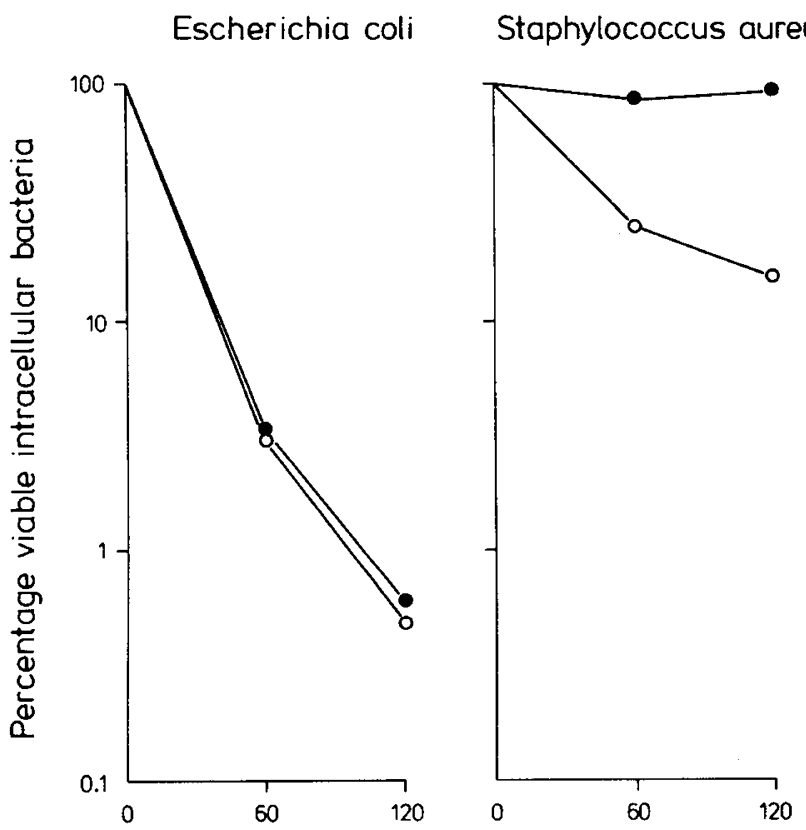

Streptococcus pyogenes Group B streptococcus
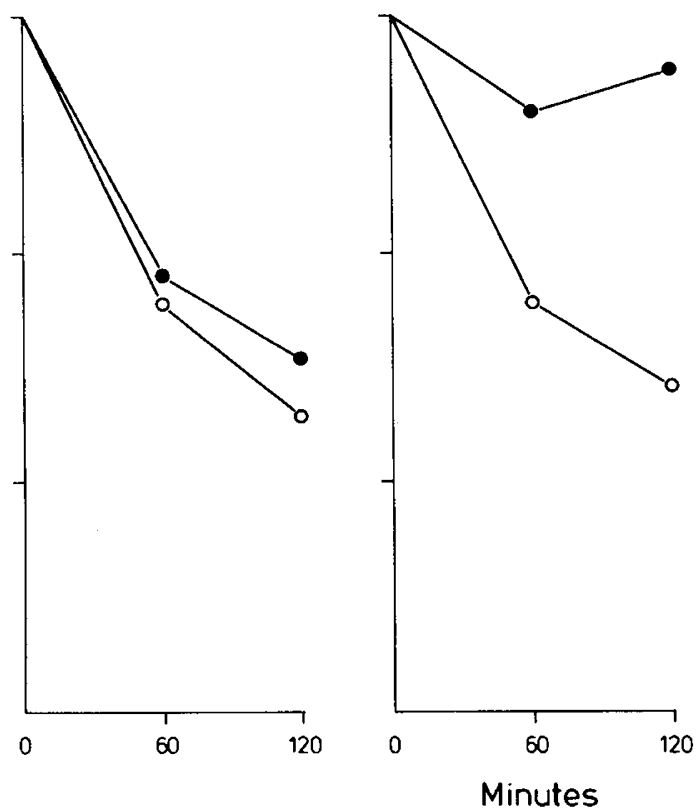

Fig. 4. Intracellular killing of microorganisms by cord blood $(\bullet)$ and adults' $(O)$ monocytes. The results are the means of five experiments with a maximal standard deviation of $13 \%$.

and $\mathrm{H}_{2} \mathrm{O}_{2}$ production during extracellular membrane triggering by opsonized heat-killed $S$. aureus, revealed that cord blood granulocytes and monocytes are as active as granulocytes and monocytes from healthy adults (Table 2).

\section{DISCUSSION}

In the present study, the main differences between cord blood monocytes and monocytes from adults were a significantly decreased percentage of esterase-positive cord blood monocytes, a decreased capacity of these cells to phagocytose group B streptococci, and a decreased rate of intracellular killing of $S$. aureus and group B streptococci by cord blood monocytes. No differences were found between the various phagocytic and microbicidal activities of granulocytes isolated from newborns and adults.

A significantly lower percentage of esterase-positive monocytes in newborns' compared with adults' blood monocytes might be due to a difference in maturaton between cells of both sources
$(10,26)$ or due to a diminished activity of the enzyme resulting in a decreased staining.

$\mathrm{Fc} \gamma$ and $\mathrm{C} 3 \mathrm{~b}$ receptors were present in similar percentages on blood monocytes and granulocytes from newborns and adults. Since ingestion of bacteria is mainly (27) mediated via these receptors, this finding is consistent with the identical ingestion of most of the microorganisms by both kinds of granulocytes and monocytes. The results of the present study also confirmed earlier reports on the phagocytic capacities of cord blood phagocytes $(7,8,20,22,25)$. Because of a similar opsonization of bacteria used in studies with adult and cord blood monocytes, the decreased rate and degree of ingestion of group B streptococci by cord blood monocytes, also found for another strain of these microorganisms (data not shown), was unexpected remains unexplained.

The rate of intracellular killing of the various species of microorganisms was similar for newborns' and adults' blood granulocytes, as well as for $E$. coli and $S$. pyogenes by monocytes. The main difference between the monocytes from the two sources 
Table 2. $\mathrm{O}_{2}$ consumption and $\mathrm{H}_{2} \mathrm{O}_{2}$ production by granulocytes and monocytes from cord blood and adults' blood*

\begin{tabular}{|c|c|c|c|c|}
\hline & $\begin{array}{c}\mathrm{O}_{2} \text { consumption } \\
\left(\mathrm{nmol} / 5 \times 10^{6}\right. \\
\text { cells } / 5 \mathrm{~min})\end{array}$ & $n$ & $\begin{array}{c}\mathrm{H}_{2} \mathrm{O}_{2} \text { production } \\
\left(\mathrm{nmol} / 5 \times 10^{6}\right. \\
\text { cells } / 5 \mathrm{~min})\end{array}$ & $n$ \\
\hline \multicolumn{5}{|c|}{$\begin{array}{l}\text { Cord blood granulocytes } \\
\text { (NS) }\end{array}$} \\
\hline Mean & 35.6 & 10 & 19.7 & 10 \\
\hline Range & $18.1-47.3$ & & $17.4-36.7$ & \\
\hline \multicolumn{5}{|c|}{$\begin{array}{l}\text { Adults' blood granulo- } \\
\text { cytes }\end{array}$} \\
\hline Mean & 28.9 & 10 & 22.3 & 10 \\
\hline Range & $12.1-38.3$ & & $9.6-34.1$ & \\
\hline \multicolumn{5}{|c|}{ Cord blood monocytes } \\
\hline Mean & 38.0 & 10 & 8.1 & 10 \\
\hline Range & $23.1-47.2$ & & $2.8-17.6$ & \\
\hline \multicolumn{5}{|c|}{ Adults' blood monocytes } \\
\hline Mean & 44.2 & 10 & 8.2 & 10 \\
\hline Range & $21.2-55.3$ & & $4.1-18.0$ & \\
\hline
\end{tabular}

$* \mathrm{O}_{2}$ consumption and $\mathrm{H}_{2} \mathrm{O}_{2}$ production were measured during extracellular triggering with $10^{9}$ heat-killed $S$. aureus. The age-dependent differences in mean $\mathrm{O}_{2}$ consumption and $\mathrm{H}_{2} \mathrm{O}_{2}$ production by granulocytes were not statistically significant $(p>0.1)$.

was the decreased capacity of those from newborns to kill ingested $S$. aureus and group B streptococci. The reason for defective intracellular killing by cord blood monocytes could be immaturity of certain bactericidal systems in newborns' monocytes. However, the normal $\mathrm{O}_{2}$ consumption and $\mathrm{H}_{2} \mathrm{O}_{2}$ production by newborns' phagocytes indicates normal functioning of the $\mathrm{O}_{2}$-dependent microbicidal systems of these cells. Therefore, another explanation must be sought for the differences seen in the intracellular killing of various microorganisms by cord blood monocytes. The results of the present study do not, however, point in any particular direction.

Identical bactericidal activities have been described for cord blood monocytes and adults' blood monocytes $(3,14,24)$, but these results cannot be considered reliable because the concentrations of phagocytic cells used in the experiments were too low (at least $5 \times 10^{6}$ phagocytic cells $/ \mathrm{ml}$ are required for reliable analysis of the results; $(16,17,19)$ and because methods measuring phagocytosis and intracellular killing separately were not used $(3,14,24,31)$. Recent investigations in newborn animals showed deficient functioning of alveolar and peritoneal macrophages $(2,29)$.

The susceptibility of newborns to group B streptococcal infections may be partially due to malfunctioning of blood monocytes and macrophages. The fact that cord blood monocytes are unable to kill group B streptococci efficiently raises the question whether the microbicidal activity of the macrophages in the liver and spleen, which originate from blood monocytes $(6 ; R$. van Furth and M. M. C. Diesselhoff-den Dulk, unpublished observations) might also be impaired such that group B streptococci are not adequately cleared from the circulation.

Another source of problems which has not been taken sufficiently into account is that all too often only one species of microorganism is used in functional studies on phagocytes. The results of the present study show clearly that comparability of the bactericidal capacity of monocytes from newborn and adult monocytes for one or two species of microorganisms does not permit the conclusion that intracellular killing of other species will also be normal.

Acknowledgments. The authors are grateful to Prof. J. Bennebroek-Gravenhorst and his staff of the Department of Obstetrics and Gynaecology of the Leiden University Hospital for supplying the cord blood samples; and to Dr. D. G. Groothuis, Rijkinstituut voor de Volksgezondheid, Bilthoven for providing various strains of group B streptococci. The technical assistance of Maria van den Barselaar and Theda van Zwet is gratefully acknowledged.

\section{REFERENCES}

1. Baker CJ, Barrett FF 1973 Transmission of group B streptococci among parturient women and their neonates. J Pediatr 83:919

2. Bellanti JA, Nerurkar L. Zeligs B, et al. 1975 Postnatal development of rabbit alveolar macrophages. J Reticuloendothel Soc 18:27b (abstr)

3. Becker ID, Robinson OM, Bazan TS, et al. 1981 Bactericidal capacity of newborn phagocytes against group B beta-hemolytic streptococci. Infect Immun 34:535

4. Cocchi P, Marianelli L 1967 Phagocytosis and intracellular killing of Pseudo monas aeruginosa in premature infants. Helv Pediatr Acta 22:110

5. Coen R, Grush O, Kauder E 1969 Studies of bactericidal activity and metabolism of the leukocyte in full-term neonates. J Pediatr 75:400

6. Crofton RW, Diesselhoff-den Dulk MMC, van Furth R 1978 The origin, kinetics and characteristics of the Kupffer cells in the normal steady state. J Exp Med 148:1

7. Dossett JH, Williams RC Jr, Quie PG 1969 Studies on interaction of bacteria, serum factors and polymorphonuclear leukocytes in mothers and newborns. Pediatrics 44:49

8. Forman ML, Stiehm ER 1969 Impaired opsonic activity but normal phagocytosis in low-birth-weight infants. N Engl J Med 281:926

9. van Furth R, van Zwet TL, Leijh PCJ 1978 In vitro determination of phagocytosis and intracellular killing in polymorphonuclear and monoclear phagocytes. In: Weir DM (ed) Handbook of Experimental Immunology, Chap. 32. Blackwell Scientific Publications, Oxford

10. van Furth R, Raeburn JA, van Zwet TL 1979 Characteristics of human mononuclear phagocytes. Blood 54:485

11. Franciosi RA, Knostman JD, Zimmerman RA 1973 Group B streptococcal neonatal and infant infections. $J$ Pediatr 82:707

12. Kaplow LS 1965 Simplified myeloperoxidase stain using benzidine dihydrochloride. Blood 26:215

3. Klein RB, Fischer TJ, Gard SE et al. 1977 Decreased mononuclear and polymorphonuclear chemotaxis in newborns, infants and young children. Pediatrics 60:467 1977

14. Kretschmer RR, Stewardson PB, Papierniak CK, Gotoff SP 1976 Chemotactic and bactericidal capacities of human newborn monocytes. J Immunol 117:1303

15. Kretschmer RR, Bekner I 1980 Group B streptococcal disease in the newborn: an immunological challenge. Infection 8:245

16. Leijh PCJ, van den Barselaar MT, van Zwet TL, Dubbeldemann-Rempt I, van Furth R 1977 Kinetics of phagocytosis of Staphylococcus aureus and Esch erichia ('oli by human granulocytes. Immunology 37:453

17. Leijh PCJ, van den Barselaar MT, van Furth R 1980 Kinetics of phagocytosis and intracellular killing of Siaphylococcus aureus and Escherichia coli by human monocytes. Scand J Immunol 13:159

18. Maródi L, Csorba S, Nagy B 1980 Chemotactic and random movement of human newborn monocytes. Eur J Pediatr 135:73

19. Maródi L, Leijh PCJ, van Furth R 1983 A micromethod for the separate evaluation of phagocytosis and intracellular killing of Staphylococcus aureus by human monocytes and granulocytes. J Immunol Methods 57:353

20. McCracken GH, Eichenwald HF 1971 Leukocyte function and the development of opsonic and complement activity in the neonate. Am J Dis Child 121:120

21. McCracken GH 1973 Group B streptococci. The new challenge in neonatal infections. J Pediatr 82:703

22. Miler I, Vondrace J, Machuldova I 1982 Comparative phagocytosis of cadmium microcrystals by peripheral blood glass-adherent cells of newborn and healthy adults. Immunobiology 162:297

23. Ornstein L. Ansley A. Saunders A 1976 Improving manual differentiation white cell counts with cytochemistry. Blood Cells 2:557

24. Orlowski JP, Sieger L, Anthony BF 1976 Bactericidal capacity of monocytes of newborn infants. J Pediatr 89:797

25. Park BH, Holmes B, Good RA 1970 Metabolic activities in leukocytes of newborn infants. $J$ Pediatr 76:237

26. Parwaresch MR, Radzun HJ 1982 The presence of isoenzymes in monocytes and macrophages. Immunobiology 161:308

27. Pross SH. Hallock JA. Armstrong R, Fishel CW 1977 Complement and Fc receptors on cord-blood and adult neutrophils. Pediatr Res 11:135

28. Root RK, Metcalf J, Ostino M, Chance B $1975 \mathrm{H}_{2} \mathrm{O}_{2}$ release from human granulocytes during phagocytosis. J Clin Invest 55:945

29. Schuit KE 1981 Macrophages and resistance of newborn rats to infection. Reticuloendothel Soc 30:341

30. Weening RS, Roos D, Loos JA 1974 Oxygen consumption of phagocytosing cells in human leukocyte and granulocyte preparations: a comparative study. J Lab Clin Med 83:570

31. Wilkinson HW 1978 Group B streptococcal infection in humans. Annu Rev Microbiol 32:41 